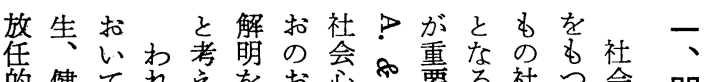

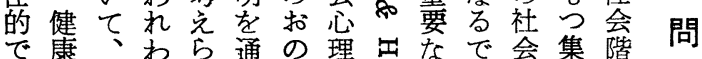
かに中れれ心の的出位あ化団層 つよ層がよて社特品置ろにとを

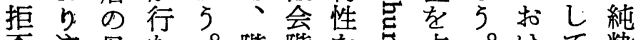
否注母な。階階を点。けて粋 的意親っ層愿市めるこる把に

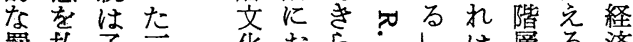

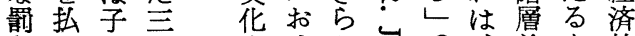

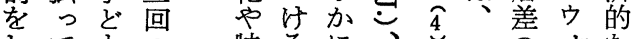

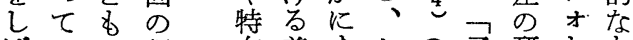

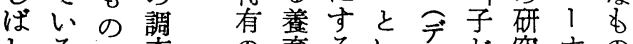
しる能香の育るいてを究ナの

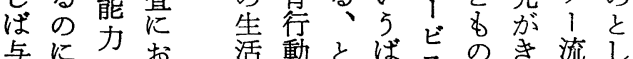

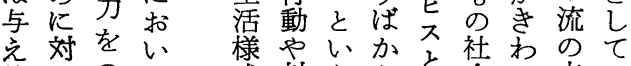
る、 と下唯底意でヴ化て場な

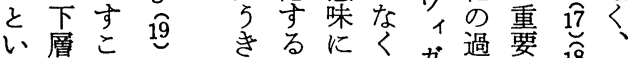

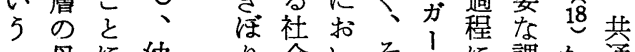
二母に幼甸会いそ不課か通 貫親熱児に化てれ和題らな しは心のさのでが、いの恃生

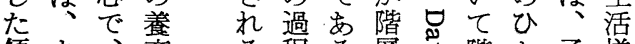

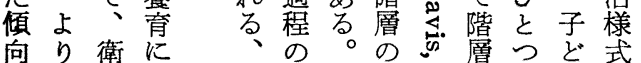

\title{
題
}

精二社閏以予そごる神的てれ社が 患

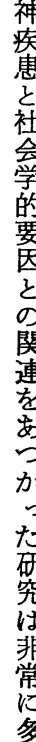

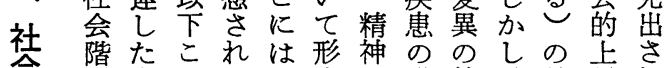
患会層分 5 る、成疾発範、差莽れ 社愿精に嘢し。階さ患生围こ密へて 会と神打視文た発関限よ接期る 学精疾い点化人生し定 $5 k$ 待

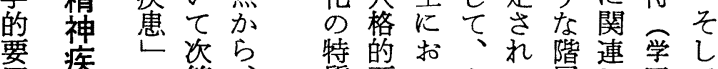
要疾の第ら、特的お賈いょて層連学し そ患問に社算界てりい文て志

の 題体会 典が、はる化い望こ

関を采学な環っ正とるやれ

連々的、的ん境き常社こ職は

をりな精市ら的り呪会と業

あ あ知神集か要とに化が的中

つ壮識医約の茵示つの示目層

かて的学、役、い過唆標々

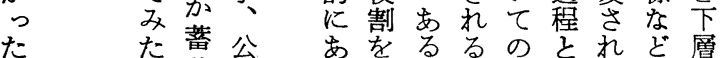

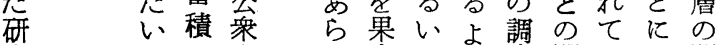

究。さ衛わ市は5香関いな間

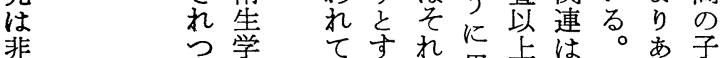

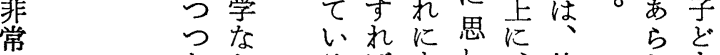

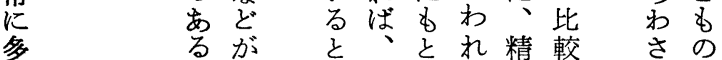

\section{波 波}

多多

野 野

梗 誼

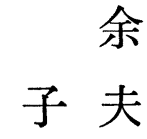


民に一し齢現会

五い方た社性に在々いて

(5) $\quad$ (四) $\Leftrightarrow \Leftrightarrow$

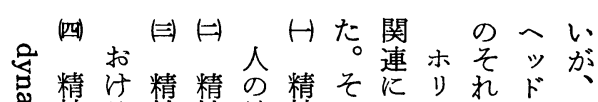

$\%$ て精会、病口 5 い層

ち調神階謷院三のる。構

ンた学の患方あ に

ダ。者イ宗者人る。拉

ムさがン教でし。壮

サら疾デ、あに彼

ンに病ッ家る打ら

プ、のク族むいは

リコ種不歴のて

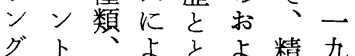

に口開りもび神五

よ1 始各に診疾 $\bigcirc$

っルの人療患年

て・時の木をのに

えグ期社リう患二

らル会ンけ者ュ

び। 期的グて存

出プ間地スい二へ

し、等位へる九ブ

同て四決ド患吾ン

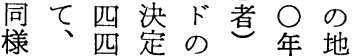

な全項し作の年域

調住目、成年月社

る

動

神る神神地神のつンでつ社

疾患科疾位疾五いグ 8 要会

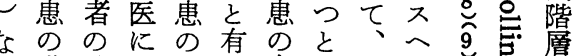

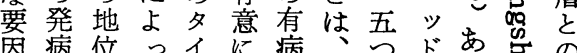

因病位つイに病

はにとてプ相率

階お関行は関

买

層计係な階し

構るしわ瘇て

造 社てれ構い

に会々る造る。

お的る。精方

は る方医意住

精 個び 的相

神公理な関

疾地㝵 治 ᄂ

患位動

病

省

鬲

はい造

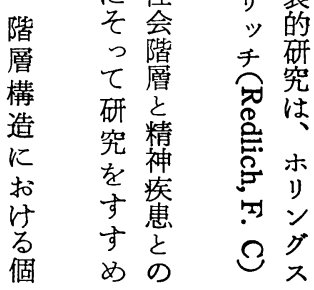

つドあ

のとろ哭関

仮々5。連

説

可㐫

考 リ

尝学充

そば レ゙

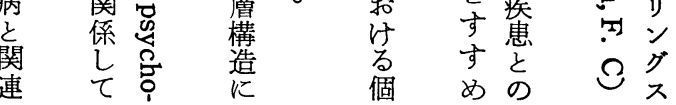

表 1 社会階層ごとの正常および精神疾患人口の分布 後 呼

\begin{tabular}{|c|c|c|c|c|c|}
\hline \multirow{2}{*}{ 社会 } & \multicolumn{2}{|c|}{ 正 常 人口 } & \multicolumn{2}{|c|}{ 精神疾患人口 } & \multirow{2}{*}{$\begin{array}{l}\text { 有病率 } \\
\text { 指 数 }\end{array}$} \\
\hline & 実 数 & $\begin{array}{l}\text { パーセ } \\
\text { ント }\end{array}$ & 実 数 & $\begin{array}{l}\text { パーセ } \\
\text { ント }\end{array}$ & \\
\hline I & 358 & 3.1 & 19 & 1. 0 & 32 \\
\hline II & 926 & 8.1 & 131 & 6.7 & 83 \\
\hline III & 2,500 & 22.0 & 260 & 13. 2 & 60 \\
\hline IV & 5,256 & 46.0 & 758 & 38.6 & 84 \\
\hline V & 2,037 & 17.8 & 723 & 36.8 & 208 \\
\hline 不明 & 345 & 3.0 & 72 & 3.7 & 123 \\
\hline 合計 & 11,422 & 100.0 & 1,963 & 100.0 & \\
\hline
\end{tabular}

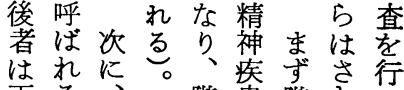

に社於表

下る、階患階き行

層内神層は愿のた

に因释 V階こ五。

ず性症で層とつこ

つ る 特 I にのの

之多呼にに仮よ

多のば 精 む 精説 5

いとれ神っ神をに

胍爷疾子疾検し

仮分心患名患討

説因思少のし集

二て性 患く有てめ

はみの者、病いら

支る精架階率るれ

持々神多層の。た

さ、疾いが指要

前患低数 1

る者之第くを数名

は一 -

資料：ホリングスヘッド・レッドリッチによる

し $\overrightarrow{\text { 般 }}$

ろ

仮に較名

説従元的

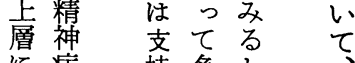

に病持多之彼 
に以三精以次衤こるに 神上社しに種のとい精 分の 社た類よがて神 裂志会 のこがう明は疾 病5堦でれちにら患 とに層焉がが、か階の

の、とる心5彼で層5

間事精 かこらあIち に実神仮なとはるの特 マの 分説るを社。一に 問裂焉愿鼻会 一精

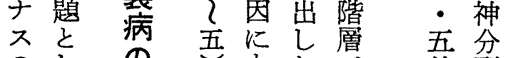

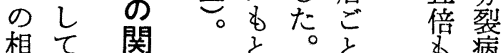

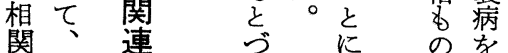
が 社

認 会

め階

ら層

水精

と神

乙疾

た患

号
に

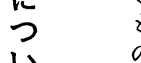

いक

て な゙瘜

惹
割 と

合

のだ

精 元

分

か有裂る

追病病々

求拉著嘴

し
表 2 社会階層ごとの神経症と精神病 の分布

\begin{tabular}{|c|c|c|c|c|}
\hline \multirow{2}{*}{ 社会 } & \multicolumn{2}{|c|}{ 神 経 症 } & \multicolumn{2}{|c|}{ 精 神 病 } \\
\hline & 実 数 & $\begin{array}{l}\text { パーセ } \\
\text { ント }\end{array}$ & 実 数 & $\begin{array}{l}\text { パーセ } \\
\text { ント }\end{array}$ \\
\hline I & 10 & 52.6 & 9 & 47.4 \\
\hline II & 88 & 67.2 & 43 & 32.8 \\
\hline III & 115 & 44.2 & 145 & 55.8 \\
\hline IV & 175 & 23.1 & 583 & 76.9 \\
\hline V & 61 & 8.4 & 662 & 91.6 \\
\hline 合計 & 449 & 100.0 & 1,442 & 100.0 \\
\hline
\end{tabular}

資料：ホリングスーッド・レッドリッチ による

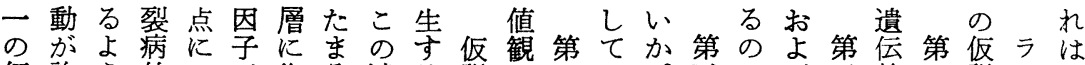
仮許 5 的つが集そ遺る説の四い。兰でび云的一説ポい

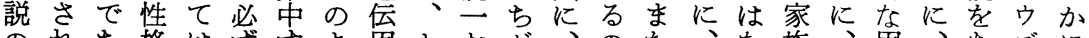

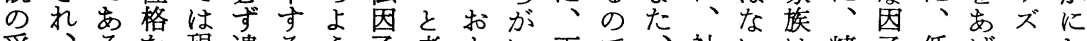
妥、るを現る5子考よい下で、社いは精子低げっし 当か乞い在伝となを爷びが層は階会か社神がいてたて

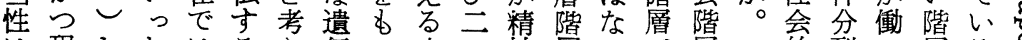
は現したはる党妘っ点は神層いご層

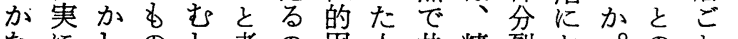
なとしのし考の因人共精裂お。 り行、のろ穵で子間通神病け 阙な現遗否れあをがで分をる わわ在伝定代る。多あ裂尊生

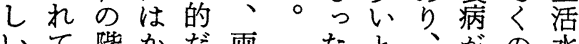
いて階かだ両ったと、がの水 よい層なと者精も考第主で準

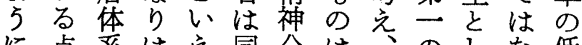
に点采は兄同分は的な低 思かにっ上じ裂下第仮ていさ

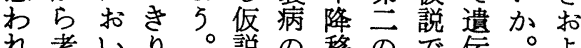
机考いり。説の移ので伝。上 るえてとたに発動そは因 び 。当は認だな病しれ市子

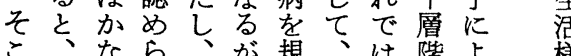

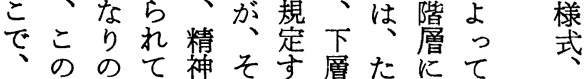

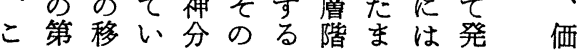

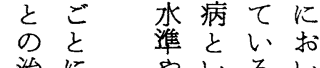

治 $k$

療 方 誈

法告

相 基

違準

がが

こ $\begin{array}{lll}5 & 2 \\ 5 & 0\end{array}$

ない 結る

秸る

にで

影は

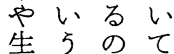
産公では

能ンは

力デな精

階の

層 故

的

市

降患

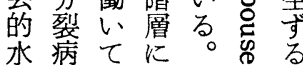

茪 で

がイい神

低办分衣

下裂

ᄂ $\%$ 病
53

は 5

11

そ

関

係

説

橗

き

き 


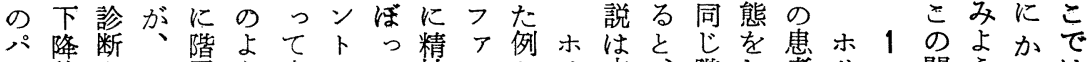

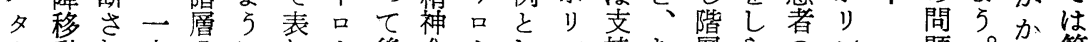

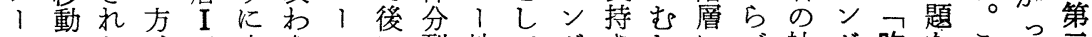

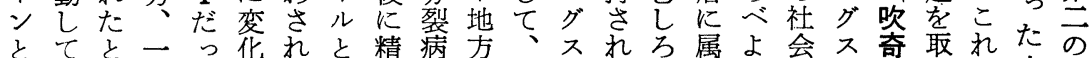
比いき九たしるし神とのラへな比う的へせりは人仮

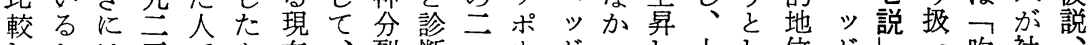
しとは吾でか在、裂断らウヴっし上し位ド先っ吹社 ては階年五をとそ病さのでのたた昇たとたのた寄会す

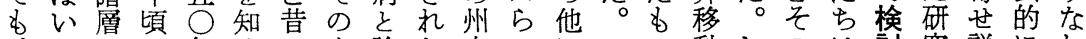
いIに年ろの人診た立のにの動しのは討究説にわ

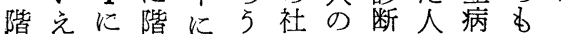
層な上愿はと会家さを院の精 的いっIV 諧的賃れ実でを神

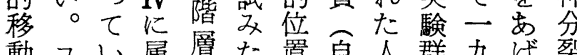
とンたし IV。動家のと四て病 精卜むてにそ四の粼し九みに 神口のい下の段場り、年よょ 分1むたが結階合に一からる 裂儿あ人っ果では住九ら。下 病にりでて市換ん元彼降 とつ、精い一ら算で吾九移 のい全神る九わ乞い年五ら動 関て体分人至すこたに云は老

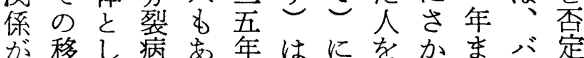
が移し病ま年はにををがな゙゙定 がしか親 多たしのの艺 い屯况き との精れに いと神を調 5 下分比查 結降裂較対 果移病 乙 象 が動患てと 出し者、な てたの社っ おす 91 会た りの \% 的精 こく両動 分 の ら 親 の 裂 仮べと実病 は止ち か。降な な可移 り胥動 ら 多 $\rightarrow$ 守 い四る。 岁尔 寄六因 点 5 と $\tau$ よい神 ばて分 れ裂

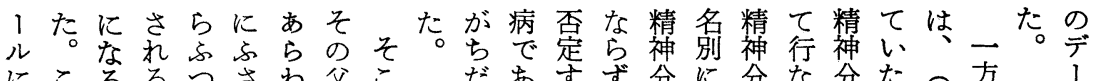

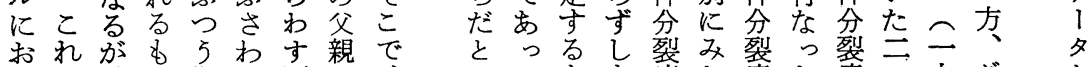

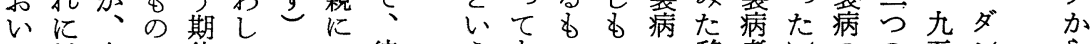
て対息で待いのつ彼 5 むのいの移者しのの五ン ら は己臬あさ職值いは基なと兄患動の父患サ八八で 父てるれ業のてささ本くはな著の社親者ブ年么 は 子、精。るに平、ら 的てみかがパ会のに・にも結 と分神そょつ均几になるなっ父タ骝職つコデ志論 も裂分のりいを教 6 様ささた親、層業いミト壳さ

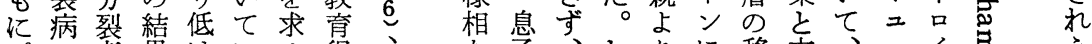
プで者果けいめ得、 ラな省杂るた点異 スいで父ばと 。集な の精は親マきこ職るっ 值神あでイがの菜た 茂疾まはナゼ值得サ 示患ら平均、柱点プ れをか值とな学光 たつにがいり歴いの すマわ5、にず精 つのイずよ職くれ神 まやナか 5 業 5 を分 りコスににがべ六裂 、ンでプあ学、段病 精卜あラら歴そ階者 神口つスわかれでと を学、し引に移本、三人活党 映父メし社意をのリ1の

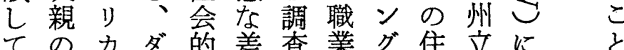
い社社ン地がしをス病よは る会会八位みて比へ主院っい

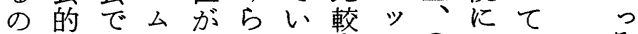
かレはは低れる导ド○はな高

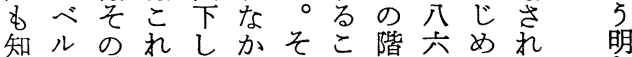
れよ人狛てっのと層名てだき なりが吹いた結に分のの研ら い上精䓫る。果よ類中入究艻 考な神せを說はた診て角らを院 えり裂をか、断、い、しでっ 
社会階層と精神疾患

表 3 精神分裂病患者とコントロールの 階層移動

\begin{tabular}{|c|c|c|c|c|}
\hline & $\begin{array}{l}\text { 上昇 } \\
\text { 移動 }\end{array}$ & $\begin{array}{l}\text { 移動 } \\
\text { なし }\end{array}$ & $\begin{array}{l}\text { 下降 } \\
\text { 移動 } \\
\end{array}$ & 計 \\
\hline $\begin{array}{l}\text { 精神分裂病患 } \\
\text { 者 }\end{array}$ & 12 & 39 & 43 & 94 \\
\hline コントロール & 19 & 53 & 22 & 94 \\
\hline 合 & 31 & 92 & 65 & 188 \\
\hline
\end{tabular}

資料：リシニタットによる

ル夫ン病出層さある。関裂

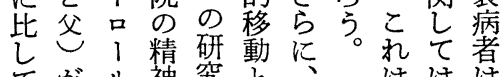
てがル神究方都注注 降較つ裂望間市必労 移さい病でのに然こ校 動れてのは関お 的かの のた、患、係けにら方 例。患者二をる期 注 がそ者九ユみ精吹待か 多のの四、よ神寄さな い結階名才ら分せれり 之果層々心を裂しる上

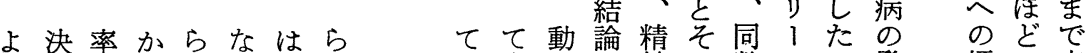

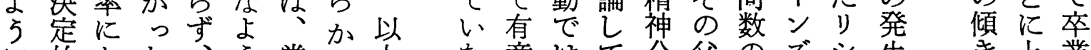
に的おた、ら常な上な意はて分父のズシ生き上業

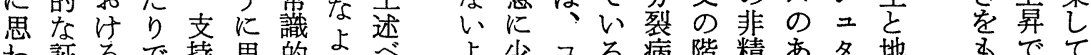

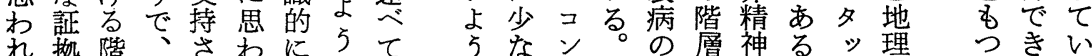

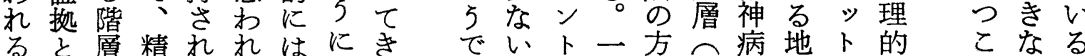

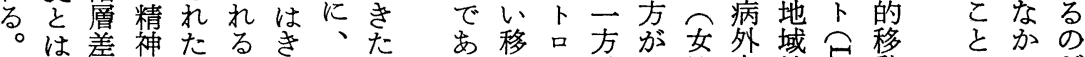
なを疾りにお第こる動 1、コ性来社岕動にるだ

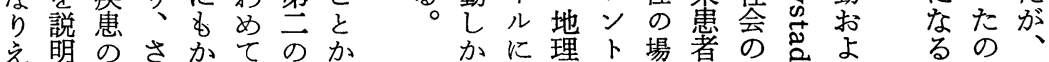

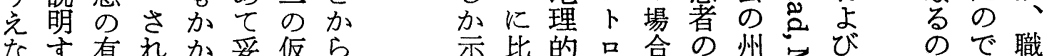

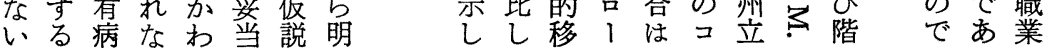

がるそはい由療た交よがてかささ率度の多っ異

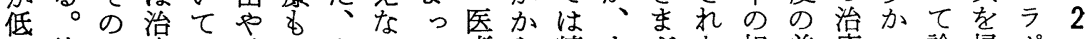
い彼た療入、入よいて者ら精まさな相差療っ診帰ポ

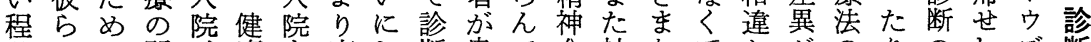
そのに開康む高し断患で分社なてとがのりのし ズ断 の研治始治に5 いての者く裂会療はなそ相少基めら・ 八究療時療関け階も病のる病的法なっの異な準よの治 1 中期し 寸な層、名社かを生へらて後がかがう第療 セよの市なるいて実を会らど活心なあの精っ異と過 ソっ患方い知々精際か階での条理いら適神たない方程 テて者法者識は神に学層市件療。わ応病りる5仮に 1ものの沙のち病はるをる 5 が法後れやのす、の説お シ 数点多寺よの意。ない若る再治るあではけ が何がでいしっ患そと識性か含の、発療、る 多ら減高のさと著のい的格にさ場とににといる診階 く治じいでか考が检 5

療る階はら発証こ無 階をの層ないら見はと意 層うでのいっれさきは識 I 忊は患かてなれわ的 二てな者。いるるるも 五いいは木よ。機て占判 分いか惠りり低し会困ろ䉼 \%すと䄈グいろ劣でなて

階はえお人層済くるとそ 層階てりッに的、。はれ II層い、ド扣理治まいに

のかし合い影関いはが断

むかのに 5 響係 5 精、と差 のわ効は心しし単神こ治 とる果、理、た純疾の療 考かが精力そりな患 万市 之、の神動れ、説がち過 るとど分的が社明確に程 か、認裂な階会々認はに

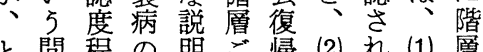
々問程の明ご帰 (2) れ(1) 層 5 ら療がのへ層機層と 問ひれに区有のこ会にの 題いる、別病態とがよ差 
表 4 社会階層ごとの受けている治療法の型なはい階がて治私 六

\begin{tabular}{|c|c|c|c|c|c|c|}
\hline \multirow{2}{*}{$\begin{array}{l}\text { 社会 } \\
\text { 階層 }\end{array}$} & \multicolumn{2}{|c|}{ 心理療法 } & \multicolumn{2}{|c|}{ 生理的治療 } & \multicolumn{2}{|c|}{$\begin{array}{l}\text { 治療うけて } \\
\text { いない }\end{array}$} \\
\hline & 実数 & $\begin{array}{l}\text { パーセ } \\
\text { ントト }\end{array}$ & 実数 & $\begin{array}{l}\text { パーセ } \\
\text { ントト }\end{array}$ & 実数 & $\mid \begin{array}{l}\text { パーセ } \\
\text { ント }\end{array}$ \\
\hline I & 14 & 73.7 & 2 & 10.5 & 3 & 15.8 \\
\hline II & 107 & 81.7 & 15 & 11. 4 & 9 & 6.9 \\
\hline III & 136 & 52.7 & 74 & 28.7 & 48 & 18.6 \\
\hline IV & 237 & 31.1 & 288 & 37.1 & 242 & 31.8 \\
\hline V & 115 & 16.1 & 234 & 32.7 & 367 & 51.2 \\
\hline
\end{tabular}

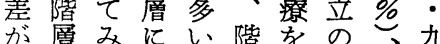

み V るよこ層受診治\%

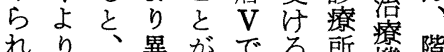

る四最なデはすな関層

歳初ら

層早精いに的多

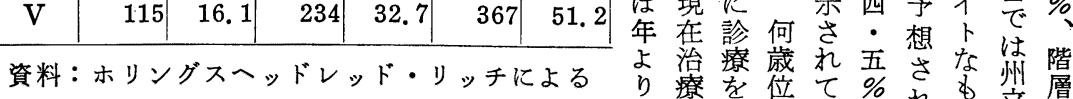

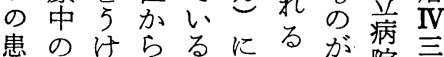

るがく条し階の 思て療りこけ患患に治。州わ多院三 こい、件か畨はこか早を高とかが者来療ま立け多より .

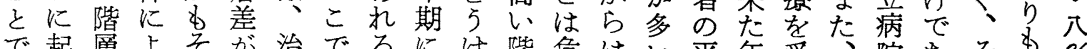

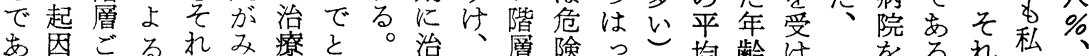
るすとばがらのく癒そのできこ年は粭発利。だ立階

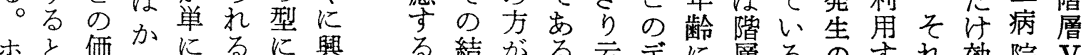

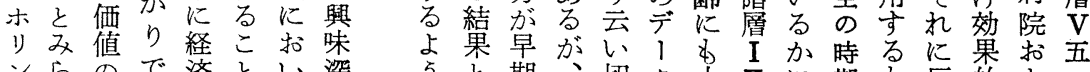

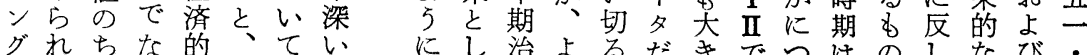

あ師のによイるセるか療類たこ十高ごすく、 $\mathrm{V}$ 的るス

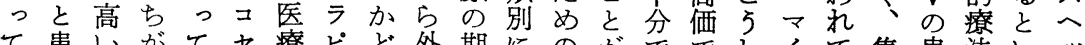
て患いがてセ療ピど外期にのがででしイて集患法いッ は者方 5 治ラス15 来間、外なああたヤい団者的だ なので療ピタに加汃(1)来いるる事、るでで電れの ら間あ階を、文は利(5)治のよをか実ス。受は炅る資 なにる層うのフわ社用治療患う考らを字壮心シ心料

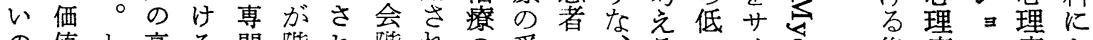
の值と高る門階れ階れの受二皇いイ吕集療ッ療よ だ体のいこの層る層て回入九だ。階コ朗団法ク法る

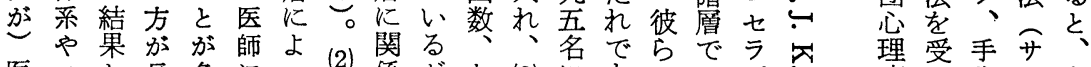

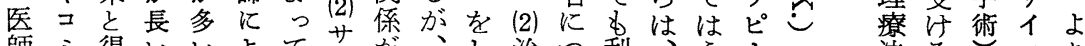

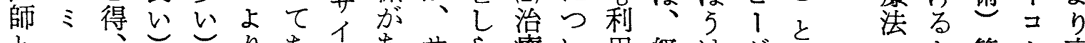

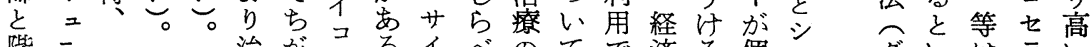
階二○(4) (3) 治がさるイベのてで済る個ェ グいはラい

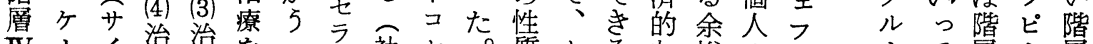

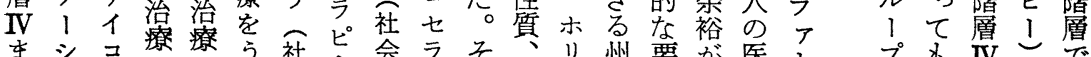

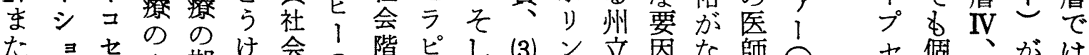

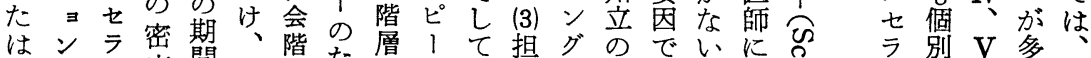

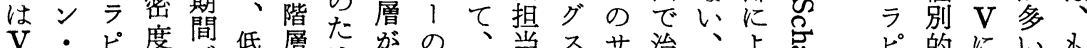

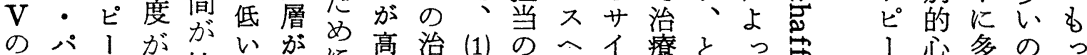

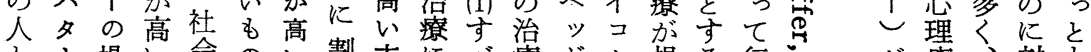
そ1場い会のい割方に心療ドセ規る行占が療、対各

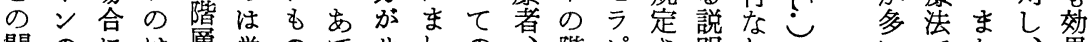
間のには層学のてサわの階ピさ明わは艺たた、果 に差は階ご生はらイさ階(4)層、れがれ艿とは階器が

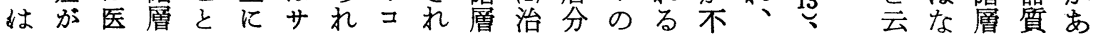




\section{社会階層と精神疾患}

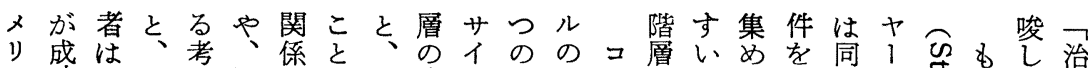

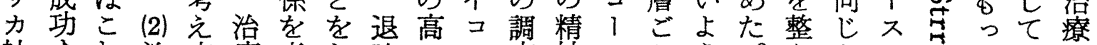

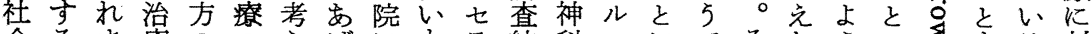

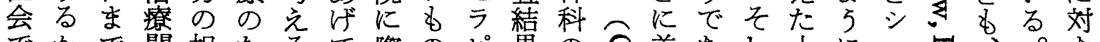

でかで関相たるて際のピ果のる差あし上にェ洁市。す

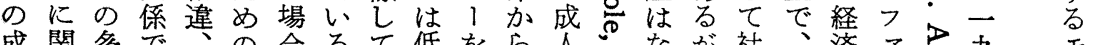

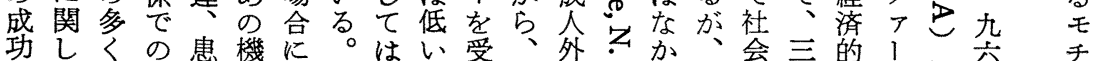

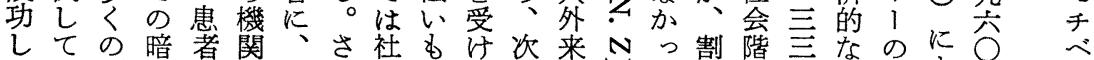

て 12 研勄がへ(1)ら会のるの部当層分要々よ年 1

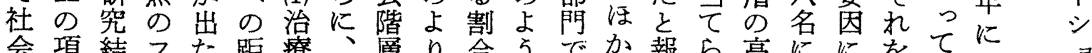

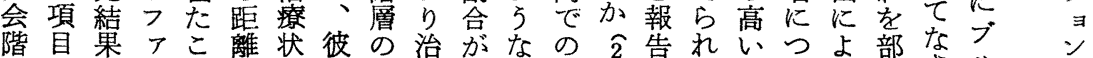

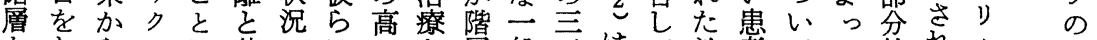

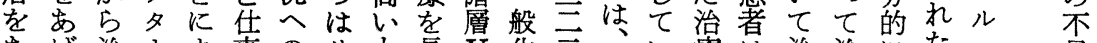

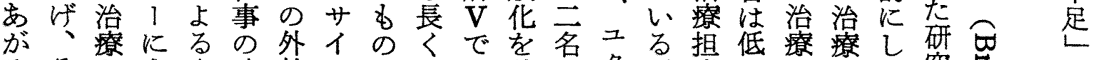

ろそを分家時的コにつは陚のタ。当いの染が究导が

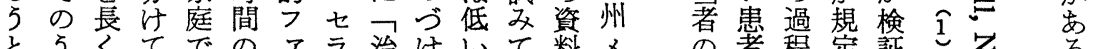

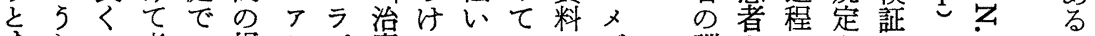

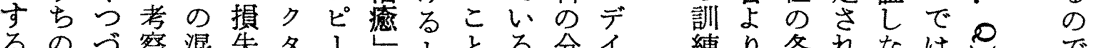

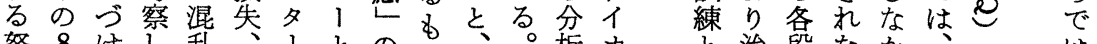

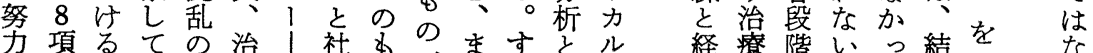

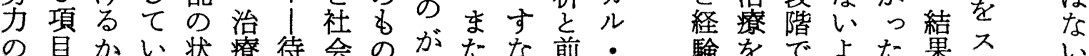

の自かい状療待会のがたな前・験を皆よた果ス、い

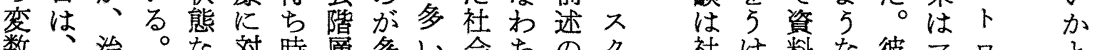

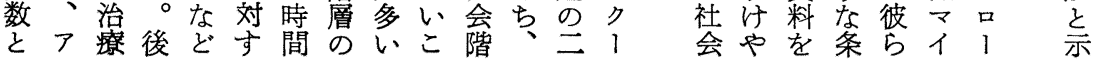

患て年めの教状とない患○なと活療、療層る的会基二

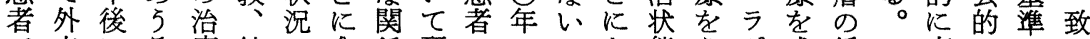
で来にる療結の分係研一のかな態ら过成低こ高にとし

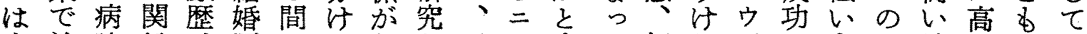
十治院係、歴にて㐫を五二すて価たズさもよ地い一い 年療でで治留検る行六1る、值後らせのう位位致る 後しのあ療年い討かな五へ説社観ののるのなに置しこ

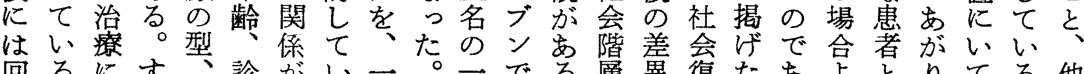

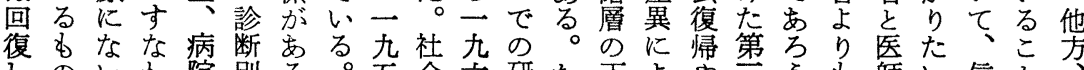

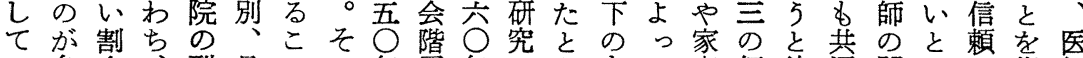
い多合、型最々の年層年の学もて庭仮彼通間のと指師 るくが社な初を結当とにフばの社へ説らのにぞ統摘々 そな増会どの報果時患おオ、に会のには価はん制しい みる加階の研告入者け口マ精階 5 含云值相でとて ら。高層効究し社院のる1イ神層け安っを互い根い専 れ一るが果のて会中そ治アヤ分ご入れてわのる気る門 る方々高を時い階のの療兴裂とれるい情人期人集

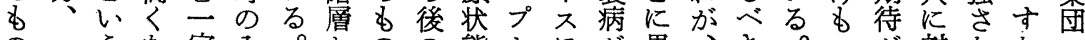
の一5な定入。とのの態とほが異、き。っが対をなの

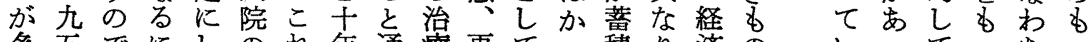

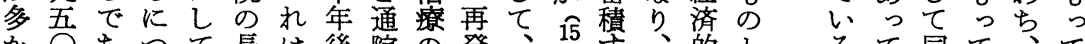

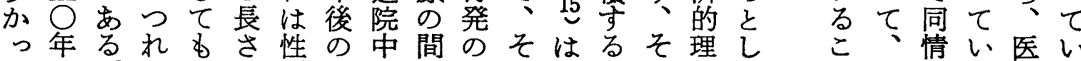
たの。てな別治のに率の立のれ沓市社る的る が外そ、括以療す有に時九でがや、杂会で社は価 来し十認前宗のの意つの五はも生治治階あ会社值 
て理わ階か病期な い的し層し率

る変いにこの治て上 で数。多の相療き文 あはとい治違のてて ろ、いこ療に方はき 5 そといあ法いた かのののかる、るよ ら発は十ん程種が で生、分だ度類まに あに精なけ関等だ る打神説に係が十こ い疾明よし現分の て患がって在な仮 む市なていの検説 治さ、る 社検に 当療れ精こ会討つ 然や5神と階はい 同復る分は層でて じ帰か裂十ごきの よのど病分と“資 5 さ 5 の想のい料 ないか患像精なは 影には者さ神い最 響働、がれ分。近 をくかよよ裂発特 及社なり5病見に ほ会り低。のの多 し心疑いし 有時 ᄂ
思び蒠し二述とはれ族社 5 社

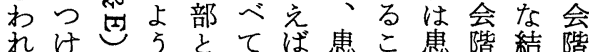
るるらとしい、著と著層果層 このしてる外をがにごかと と精て、。来家で必々らの に神い退マ治庭き要の、関 よ疾る院イ療でなな差つ連 り患よ後ヤ施看いめがコは に5 の 1 設護。んあ⿱丶万卜 い対で患スを导こどる二院 っすま者は利るれらの二患 そるるの、用こにをだテ者 5 が地現すとひみろれと 問般、域在るをきたうに同 題公こ社進このかり。帰様 が采れ会行とぞ六、社つの 解のらお中方む患会て傾 明態とよのでと社者階き向 さ度カびフき同会の層たを れのミ家オる時階たの患示 る研ン庭口のに曾めと者し

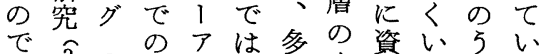
は 3 適ッなく高源的ける。 ななミ応プいのいをの入。 いど导を研か資家手でれこ か子忌追究し源族には方の

ス視はれ社因お説こ

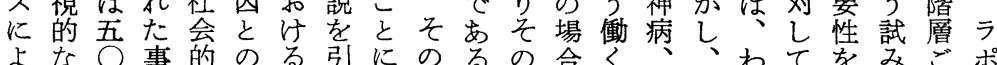

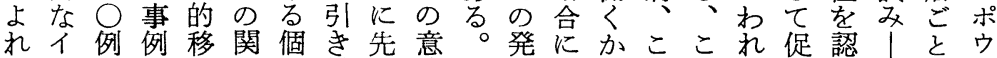
ばンの研動係人継駆味

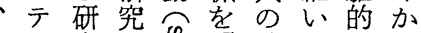

こン究 $气$ 。 明地でなら の 研イい昌にら同のる 究ブ 5 志志か精じとと、

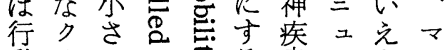
動りい岕る患1なイ 科二ケ怘したのへ 学カイの や・・壳割おににらと 精スス岂をよおおは品 神タタ研びけい、゙ 病デデを究、るてホ、 学 11 行 す (2) 社、リ 者ででなる精会 (1)ンの のああった神的社グ研 ᄀるるてめ障心会ス究 文、がいに害理階へ全 とイよっう統お動構ドは、 1!微れさる要に仮ま

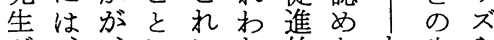
が、、ににれ的なむ生ら 規神は精つのにいち活に 定経っ神い観あわら様よ さ症き分七点る汗ん武る れなり裂のかいで、や第 てど概病実らはは精文四 いと念に証は素な神花の るは化つ的亩い分の仮 ちさい資っの。裂ち説 と肪れて料々形儿病が みってはは古成かの心す るてい皇とし興とな 精、なそわ味い、生関わ 神。いのめ市 5 社に連ち 医った発てる形会沶さ、 学ぱめ生少もで文壮せ精 者らでになの働花るて神 も遗ま社いとく的遗解分 少伝万会。认之要伝釈裂 な的 5 的こ光考因的し病

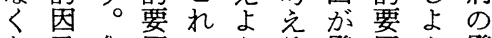
な子分因は5 る発因5発 いに裂が、。病のと生 四 のよ病ど精し|に重いを 


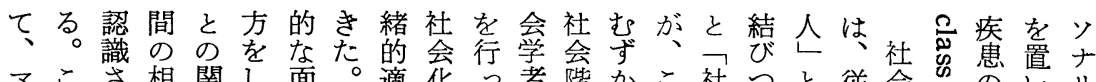

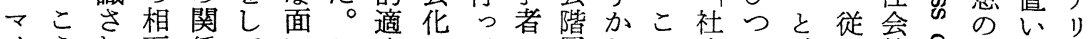

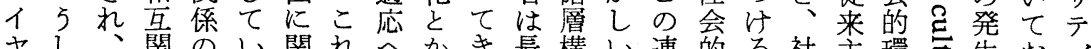

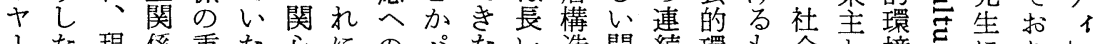
にた現係重た心にのパたい造問続環も会々境密にりし

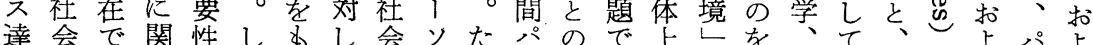

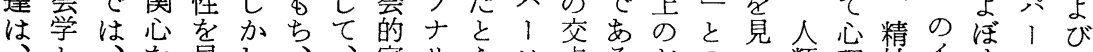

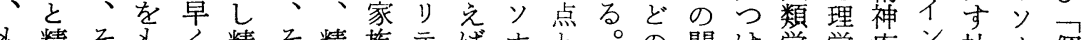

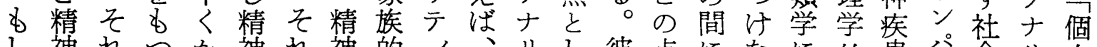
し神れつか神れ神的ィ、福彼点になに的患分会り人

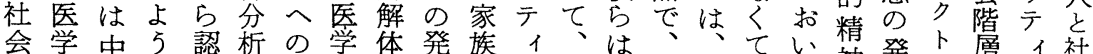
会学中 5 認梠 9学体発族1、家、、、てい神発卜層1社

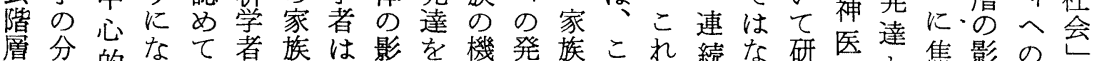

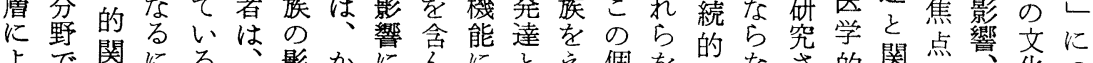

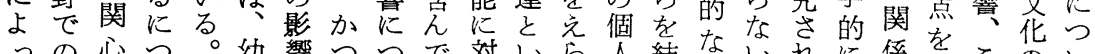

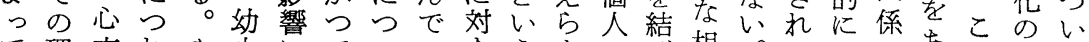
て理事れや少にていいす

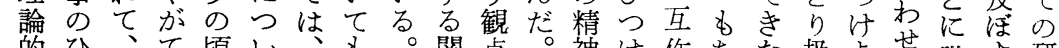

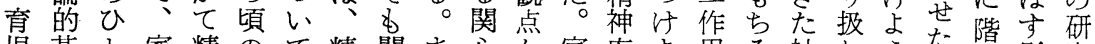

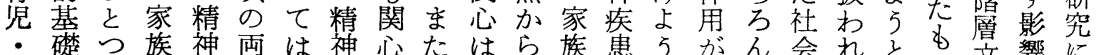

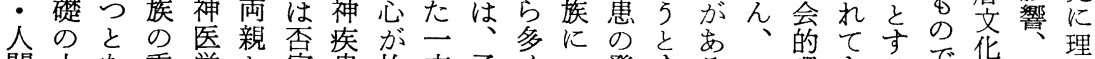
間上な重学々定患払方子くつ発方るつ環きるで化特論 相にっ要者子的のわでどのい達るわ個境たと市すにに的

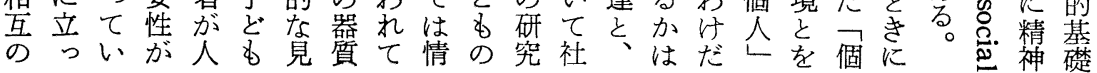

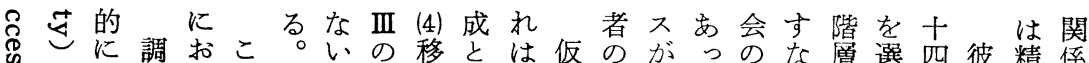

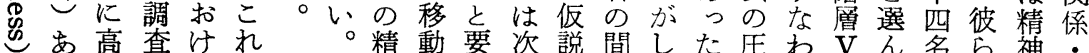

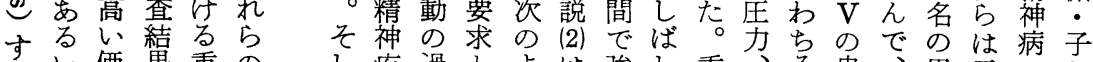
ない価果重のし疾過と治し重交患男三のど おは值に要こて患程のう部かば要精れ者さ女ら発す

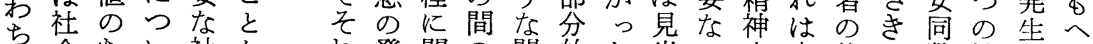
上会市社か発関の問的た出こ疾家体の数社にの 香的るて会ら、慆生連ず題にこさと患族験仮の会関役 移受の簡的、階と学れをはとれはに相の説患階係割 動容は単要階層はる、含支で主対互間を者層梦期

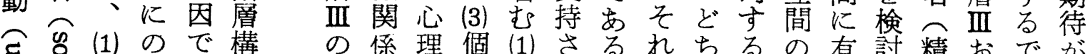
ミ气(1) ので構 の係理個 (1) さるれちるの有討精おでが 过レベあ造神が学人達れ。はら態役意し神よ市違

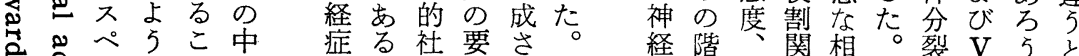
马

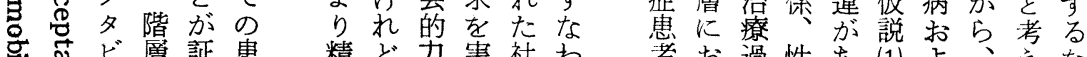

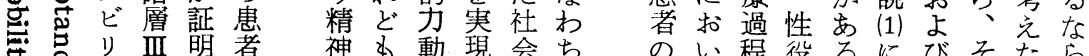

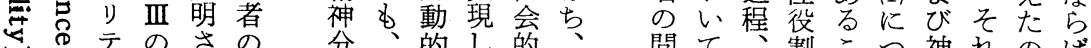

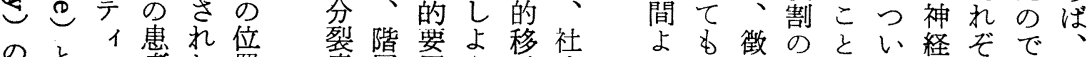

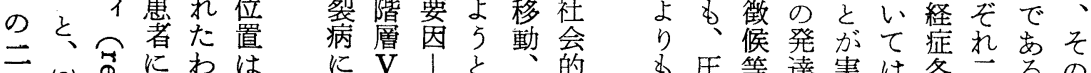

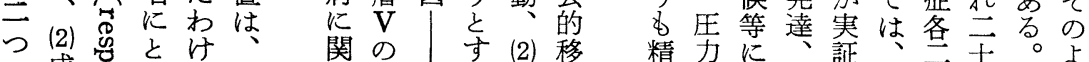

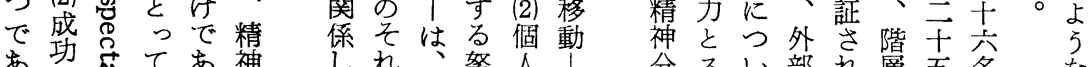

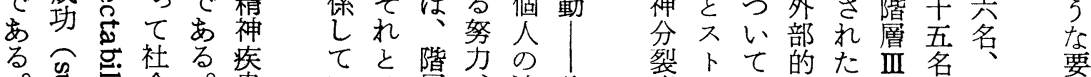

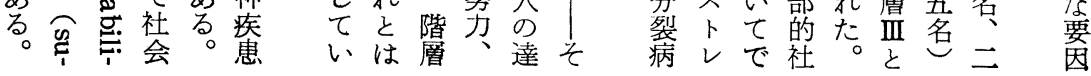


師』さでこは態りっはた愛件、臨と動達に徳夕を教両

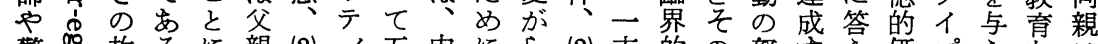

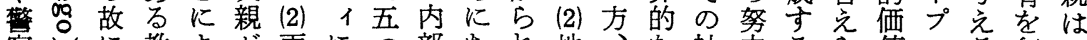
察しに教よが両につ部あれ地なな社力るら值のる行こ なを自師る酒親不の的まる域階っ会のとれとス。いの ぞ持分、もをに幸互なりこ社層哥た次なのトこ、气

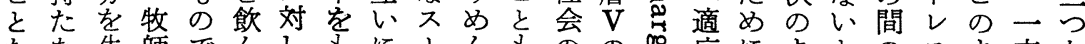

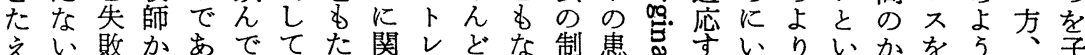

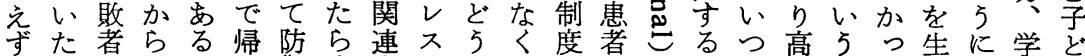

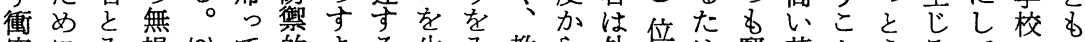

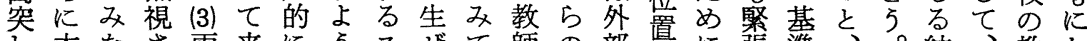
し本なさ両来に5スぜて師の部直に張準、、結、教た て能すれ親てなな卜しもと孤的し態のがそ(2) 果外師た

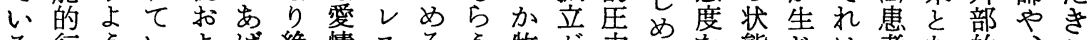
る行 5 いよば絶情スる5 牧が力竞態じは者な的、こ 動にるびれ学やが。こ師あとい变にて欲はる圧牧も をなと兄る势保生マとかるしる容い来求彼。另師 5

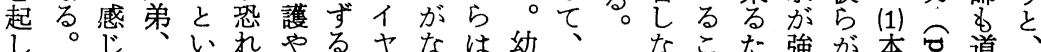
し。じ、いれやるヤなは幼、なこた強が本导道

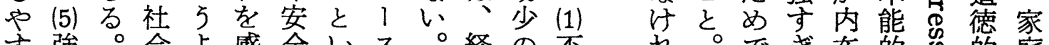
す強。会上感全い不経の不杂。でぎ在的导的庭

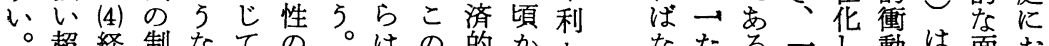

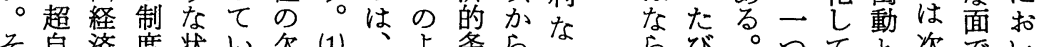

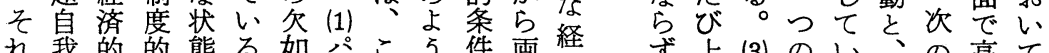
れ我的的態る如八こ5件両経齐上(3)のい文の高て 故不代㤎。し、れなが親済、昇上基る高兰、厳

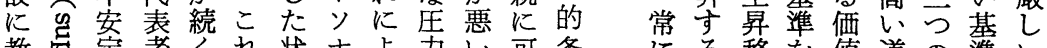
教它空者くれ状ナよ力い可条にる移を值道の準い

五四三二

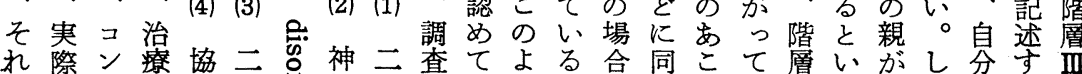

(4) (3)

(2) (1) 一专認 ベ者な皆たてな分すはら

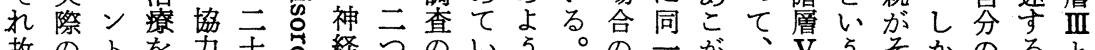

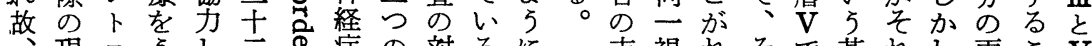

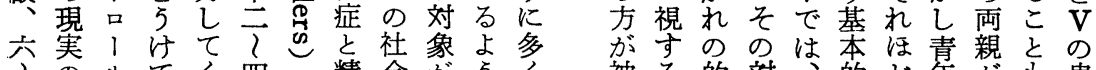
々のルてく四だ精会が 5 く 七状・いれ十だ神階少にの 歳態グるた歳を分層数、興 までル精患ま取裂だ䈐こ味 でな1。神著で取病汗集のあ

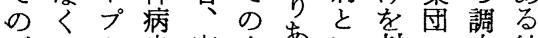
デ回を患家人夜い対に查結

1 想々者庭だ壮 5 象限に笨 夕にらにに腹光にらはが がたなつつでいうしれ限得 不よかいいある。の施ら 定っっててる機いいがれ

してただの能るるあて

てい。けみ れる。調調 る。查香 さ し
た。
た
的。文

疾

患

寄

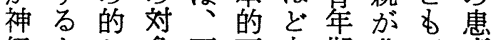
経よと象両不立期非で著 症 5 なが親連派に常きの 患にる全な続に至にる。特 者な。くら性はる立。漼 にる野欠びにみと派階は 比。球如に問方社な層同 較このし先題な会人 $\mathrm{II}-$ しの選て生がく的にの視 て同手いにあな成み患

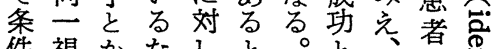

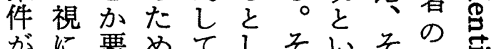

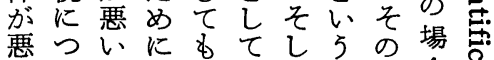

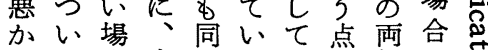

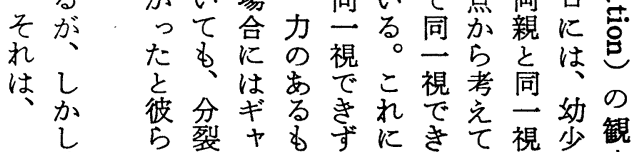

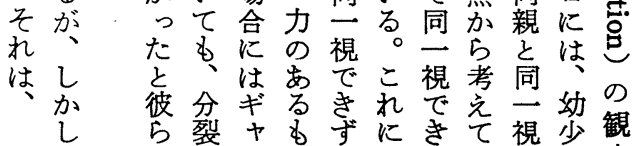

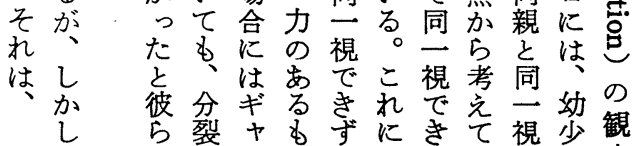

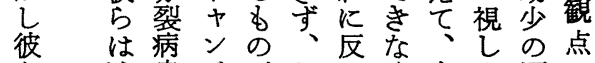
述患グがししく自や頃か 


\section{社会階層と精神疾患}

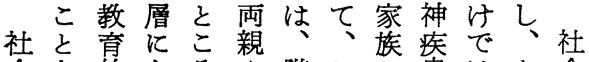
会を的あろや階こと患はか会 階指作たか教層のののつ階 層 摘用るら 師 III よ相発のつ層

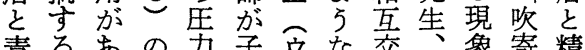
青るあの力方市交我象寄精 の の 人でにに張にナ㚙沶の分患 格あ少は肪成 15 社なる。 形っし、生功流行る会説、有 成たし経ずやのな階化明診病 の。少済る上中わ層のを断率 領与的の昇のれ美過与文 域党移下た居程光治の に ら社、動のマ应に療 お会階の階イ考おいにに

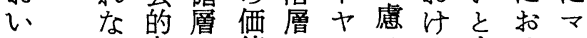

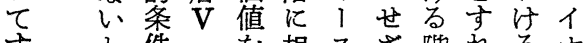
す件劣相スさ階れるナ でこの同教当とる愿ば階ス にろたし兄し口を文、層の

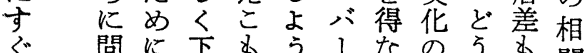
え゙ 閏に长

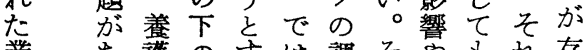

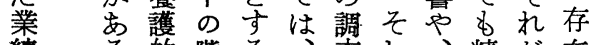
績る的階る、查し、精だ在
五ば同瘜ばきすべ関六 要 ま家のなしたて原社 ま内因、おこ患社階 だでとそ汀の者会層 残すなので研に的別 さ病るなは究当当 れ気のかなに精神 たにででいおおは神経 問なはの。いま的症 題るな家彼てる 特 は人い族 5 女分徽 多之か関は社いが裂 いなと係社会 5 か病 とら述の会階わなに いなへ違階層㚈らよ わいてい層とでずっ ないやが精はして け人る、精神な的分 れが。役神疾い之梳 ばあし割疾患。のら なるかの患々 れ らこし違のの ルる なと同い直関、 グ

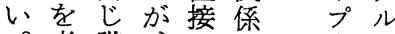
。考階、のが 中 れ層精原は の神因った

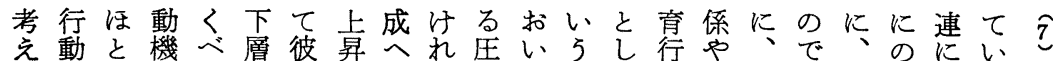

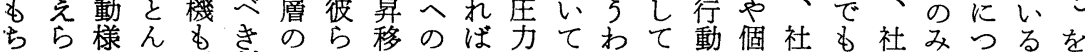

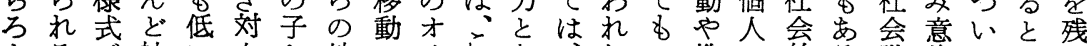

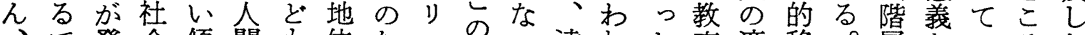
、で発会傾関も位たエのる達れを適移。層をのるた

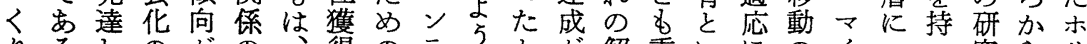

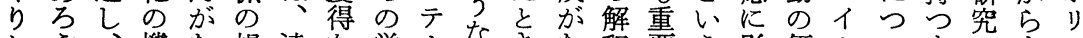

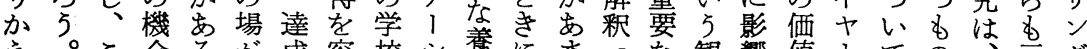

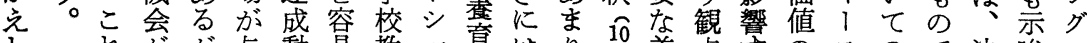

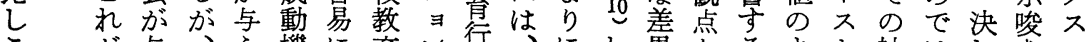

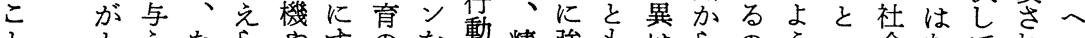

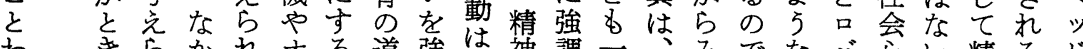

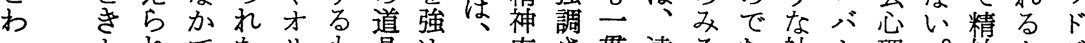
っ れでなりも具め子疾さ貫達る あ社 1 理。神よが

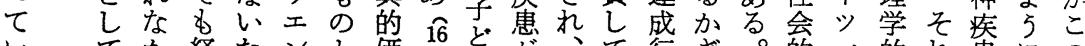

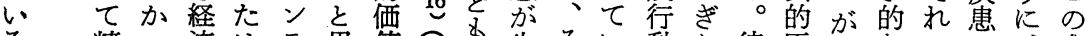

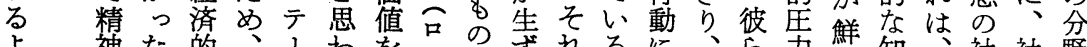

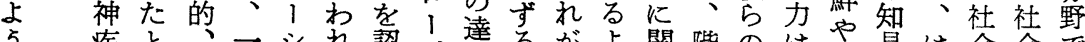

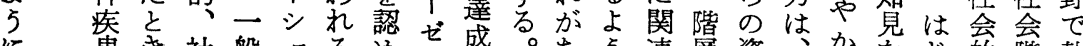

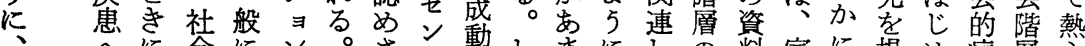

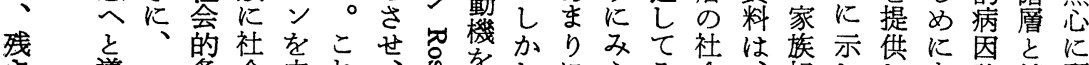

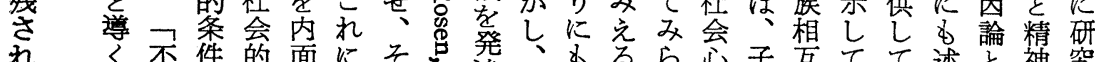

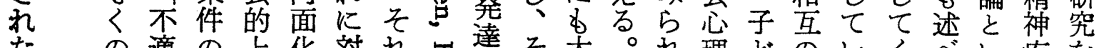

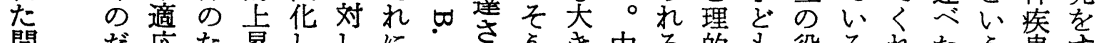

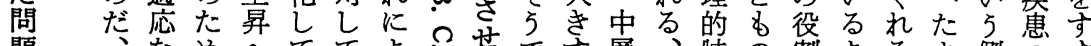

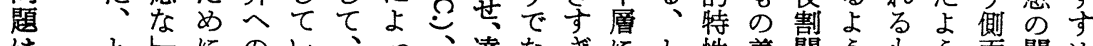

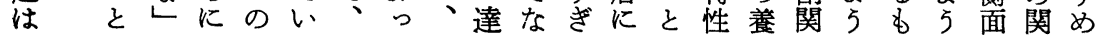




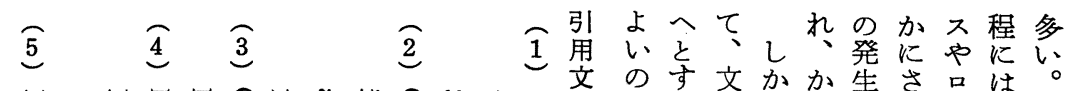

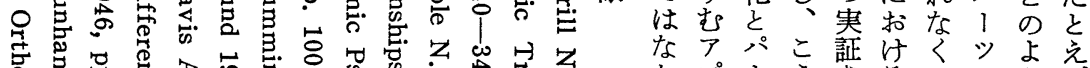

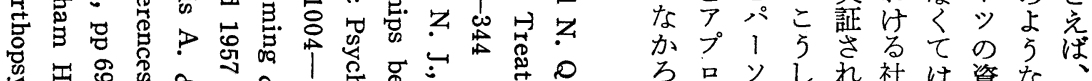

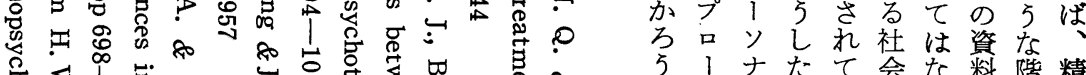

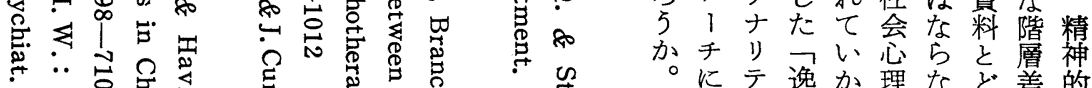

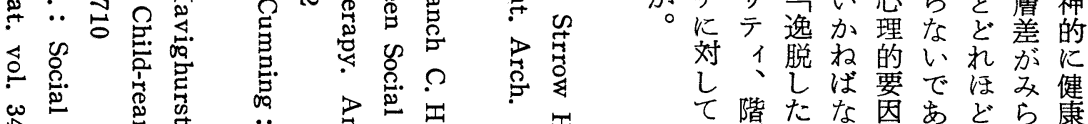

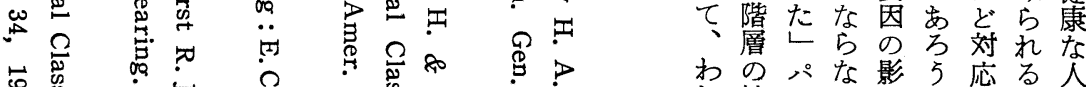

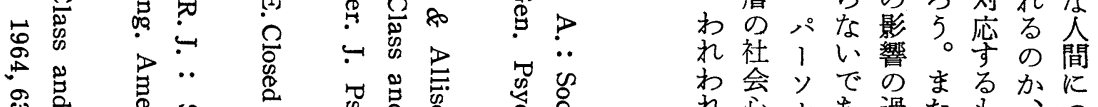

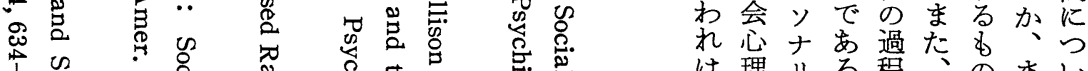

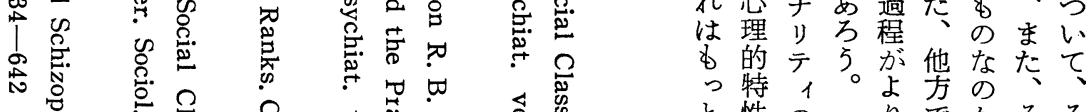

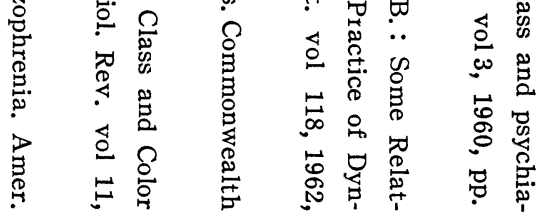
と性の可でかそ 関の形ははがれの

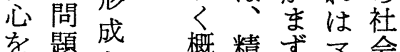
抬題を概精ず会 口解通苝疾きャ货 $\tau$ 明乙さ患ら１過

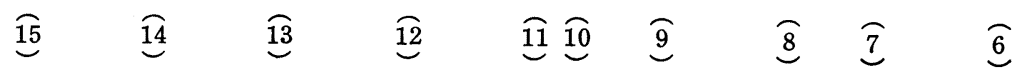

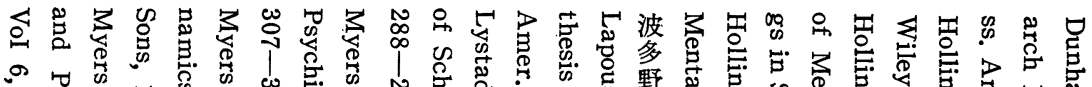

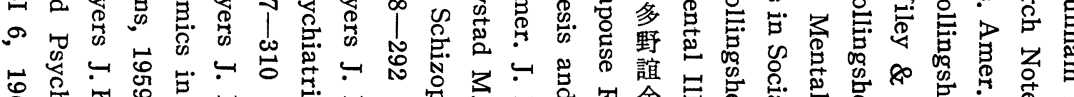

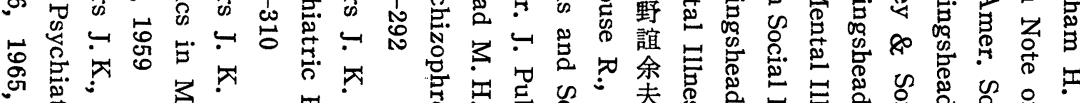

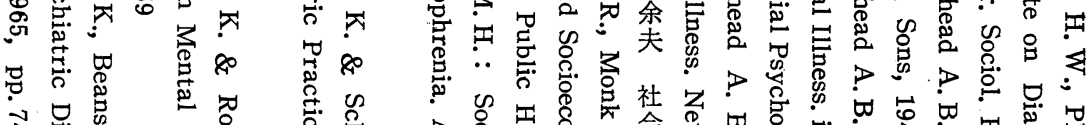

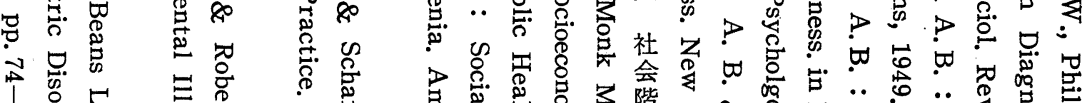

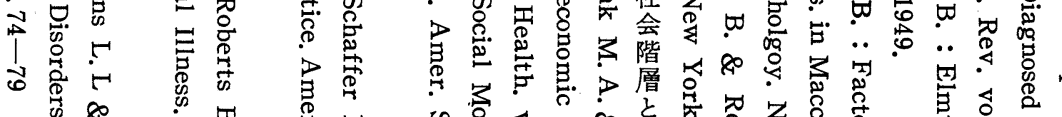

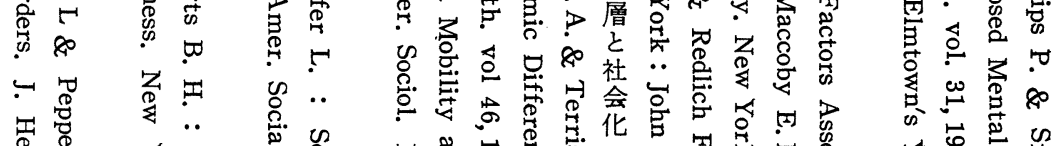

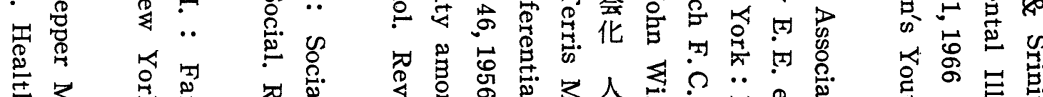

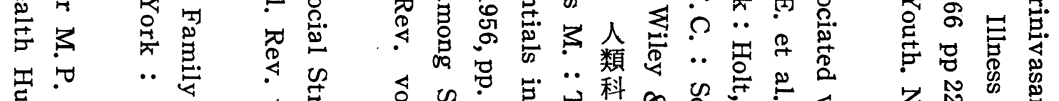

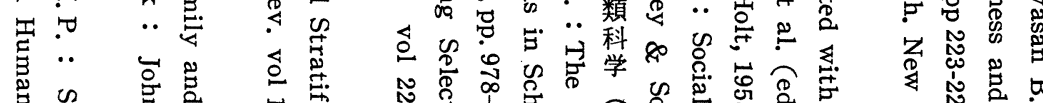

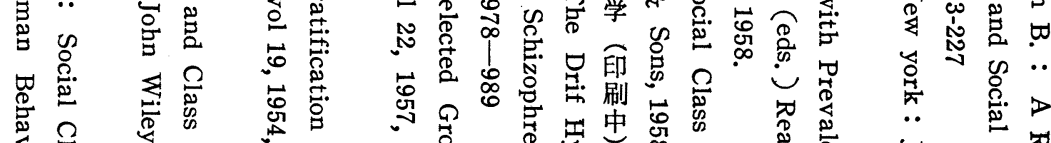

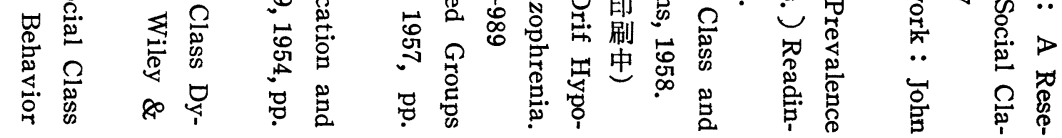


社会階層と精神疾患
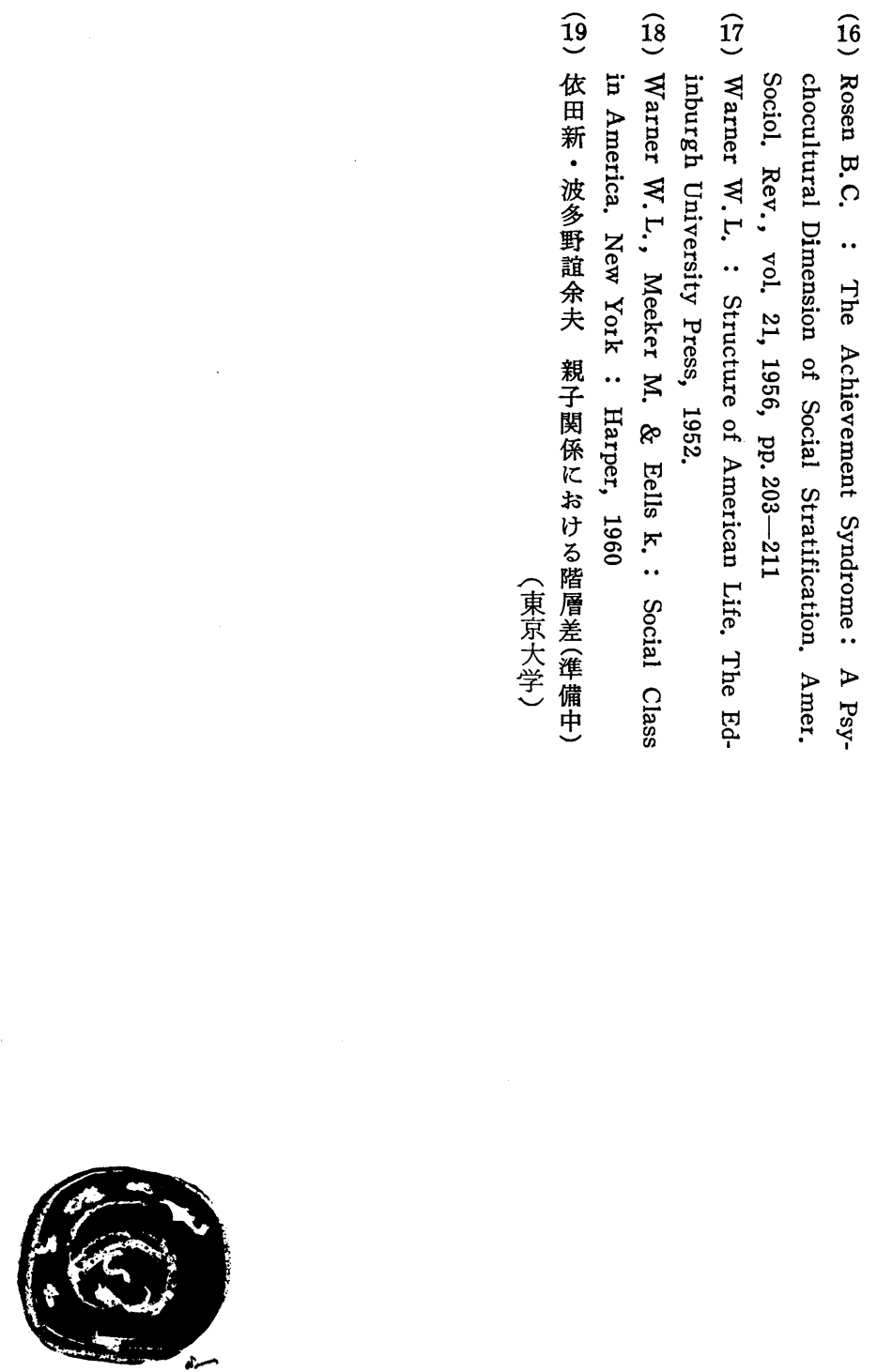
the problem of bureaucratization in the organization of local educational administration.

\section{SOCIAL CLASS AND MENTAL ILLNESS}

\section{Kyoko Hatano \& Giyoo Hatano (Tokyo University)}

Research findings concerning social class differences in mental illness were reviewed. These studies made significant contributions to social-psychological analysis of social class characteristics as well as to social etiology of mental illness.

Many studies, e.g., Hollingshead \& Redlich, clearly indicated that there was a negative correlation between social class indices and the prevalence of mental illnenss. (The lower class showed a high rate of prevalence) Three types of explanations were suggested to account for the difference : Some researchers examined "drift hypothesis", which reduced differential prevalence to heredity factors and asumed downward mobility of the mentally ill. Evidences were not consisistent on this point. Others tried to demonstrate social class differences in diagnosis and treatment. These factors, though seemed to have some effects, were probably not the only ones that made the difference.

The third explanation, which was the most attractive for educational sociologists, was that social class sub-culture influenced socialization process of a child and social interaction of family members. It seemed reasonable to interprete the findings, especially the one by Myers \& Roberts, as follows :

1) Ir class III (lower-middle class) parents and teachers expect and encourage a child's success or upward mobility so intensely that, in some instances, social stress and tensions are produced, which lead to maladjustment, but generally they develop a child's high achievement motive.

2) In class $\mathrm{V}$ (lower-lower class) lack of adequate nurturant and educating agents develops socially deviant or "maladjustive" patterns of 
behavior, which bring about mental illness in the most severe cases.

\section{SOCIAL DISTANCE BETWEEN JAPAN AND THE UNITED STATES}

\section{Tsuyoshi Ishida (Hiroshima Institute of Technology)}

The study tries to get various infomations on how Japanese look to American students as well as on evaluating the social and psychological distance between Japan and the United States. Systematic framework revised from the one which was constructed for nation's prestige index measurement says that knowledge, feeling and understanding of another country are aspects of a nation's attitude to that country. Feeling and understanding have certain amount of scale in measuring these aspects of a nation's attitude but knowledge does not. On knowledge we know just it is right or wrong. Apart from the components on measuring the nation's attitude, you may say that someone constructs a nation's attitude from vague image of a country. I suspect that this kind of image might be applied for the nation's attitude when a respondent does not have any idea on a specific aspect of a nation. Thus, according to my frame of reference of evaluation system of a nation, the attitude which has such three aspects is put parallel with social evaluation as I defined or so called synthetic evaluation of a nation. The attitude and the social evaluation are interrelated in its nature.

Besides the evaluation system, the study has tried to construct a social distance and psychological distance between the nations. Here we suppose that some nations might be evaluated highly because of emotional feeling, but others do not. Then, in a distance system it is determined that the former constructs a psychological distance and the latter a social distance. Findings: The American students have evaluated Japanese relatively highly, but from analysis of the difference among the aspects of the attitude we know that their score on knowledge is higher than the one on feeling. From social evaluation of Japan we could know that Japan is now ranked in a group of the second class developed countries in the world but 